\title{
ESTILOS PARENTAIS E AS IMPLICAÇÕES NO DESENVOLVIMENTO AFETIVO ENTRE PAIS E FILHOS ADOLESCENTES
}

Fernanda D'Avila Rodrigues ${ }^{1}$

Dioneia Luciane Mendes ${ }^{2}$

Resumo: A adolescência é uma fase de intensas mudanças físicas, cognitivas e psicossociais, colocando o sujeito em um período inquieto pela busca de novas sensações, criando alguns conflitos no entendimento dos pais diante essa fase. Desta forma, Baumrind (1966) assinalou estilos parentais diferentes entre si, mostrando que um determinado aspecto do comportamento parental é dependente da configuração de todos os outros aspectos da adolescência. Esta pesquisa teve por objetivo identificar os estilos parentais de 06 pais de adolescentes em tratamento psicológico em um Centro de Atenção Psicossocial no Litoral Norte do Rio Grande do Sul - RS. Trata-se de uma pesquisa qualitativa do tipo exploratória. Os instrumentos utilizados foram Questionário Sociodemográfico, Entrevista Semiestruturada e Inventário de Estilos Parentais de Gomide (2006). A análise das entrevistas foi realizada de acordo com o método de Bardin (1977) e o inventário de acordo com o manual de correção. Os resultados obtidos mostraram entre os entrevistados os Estilos Parentais de Risco, Bom e Ótimo, correlacionados e analisados diante comportamentos de convívio familiar, estabelecimentos de regras e comportamentos dos filhos adolescentes, correspondendo também com índices sociodemográficos.

Palavras-chave: Adolescência; Vínculos parentais; Estilos Parentais; Comunicação afetiva.

PARENTAL STYLES AND THE IMPLICATIONS IN THE AFFECTION DEVELOPMENT BETWEEN FAMILY AND TEENEAGERS

\footnotetext{
${ }^{1}$ Acadêmica do Curso de Bacharelado em Psicologia da UNICNEC.

${ }^{2}$ Mestre em Psicologia pela PUC-RS. 


\begin{abstract}
Adolescence is a phase of intense physical, cognitive and psychosocial changes, placing the subject in a restless period of search for new sensations, creating some conflicts which the parents. Thus, Baumrind (1966) pointed out different parenting styles, showing that a certain aspect of parenting behavior is dependent on the configuration of all other aspects of adolescence. This research aimed to identify the parenting styles of 06 parents of adolescents undergoing psychological treatment in a Psychosocial Care Center in the North Coast of Rio Grande do Sul - RS. It is a qualitative exploratory research. The instruments used were Sociodemographic Questionnaire, Semi-Structured Interview and Gomide Parenting Styles Inventory (2006). The analysis of the interviews were performed according to the method of Bardin (1977) and the inventory according to his correction manual. The results showed among the interviewees that Parental Styles of Risk, Good and Great, correlated and analyzed in relation to family living behaviors, rules and behaviors of the adolescent and children, also corresponding to sociodemographic indices.
\end{abstract}

Keywords: Adolescence; Parental bonds; Parenting styles; Affective communication.

\title{
1 INTRODUÇÃO
}

A adolescência é uma fase de intensas mudanças físicas, cognitivas psicossociais, que coloca o sujeito em um período irrequieto de busca por novas sensações. Os adolescentes muitas vezes omitem da família alguns problemas e preferências, aumentando assim sua insegurança. Sucedem a este período a perda progressiva da autoridade dos pais e a crescente autonomia de seus filhos. Dessa forma, incorporando às diversas questões culturais, econômicas, sociais, religiosas e afetivas, podem criar nos pais uma grande dificuldade de comunicação com seus filhos e, consequentemente, a falta de oportunidade de conhecer suas atitudes e experiências de vida (RUZANY, et al 2008).

De acordo com Osório (1996), a família possui um papel primordial no amadurecimento e desenvolvimento biopsicossocial dos indivíduos, apresentando algumas funções primárias intimamente relacionadas: funções biológicas (sobrevivência do indivíduo), psicológicas e sociais. 
A função biológica da família é garantir a sobrevivência da espécie humana, fornecendo os cuidados necessários para que a criança possa se desenvolver adequadamente. Em relação às funções psicológicas da família, destacam-se três fatores: a) proporcionar afeto ao recém-nascido, aspecto fundamental para garantir a sobrevivência emocional do indivíduo; b) servir de suporte e continência para as ansiedades existenciais dos seres humanos durante o seu desenvolvimento, auxiliando-os na superação das "crises vitais" pelas quais todos os seres humanos passam no decorrer do seu ciclo vital (um exemplo de crise que pode ser mencionado aqui é a adolescência); c) criar um ambiente adequado que permita a aprendizagem empírica que sustenta o processo de desenvolvimento cognitivo dos seres humanos (OSÓRIO, 1996).

Já na função social da família, o centro está na transferência da cultura de uma dada sociedade aos indivíduos e na preparação dos mesmos para a cidadania, sendo assim, é a partir do processo socializador que o indivíduo elabora sua identidade e sua subjetividade neste contexto (PRATTA E SANTOS, 2007).

A adolescência tem se caracterizado como uma fase de emoções intensas, na qual o sujeito está em busca da sua identidade afetiva e social. Diante deste processo, ocorre o afastamento da família de origem e um maior envolvimento com o grupo de semelhantes. As características próprias da fase adolescente são expressas através de comportamentos e desejos ambivalentes, definindo como os jovens vivenciam e relatam as suas experiências familiares. De tal modo a comunicação entre os membros da família se torna elemento fundamental para potencializar e auxiliar o estabelecimento de relações mais assertivas e saudáveis. Porém o adolescente está cada vez mais solitário em relação a sua família, pois os pais tendem a estar preocupados com o sustento da casa, em ganhar dinheiro e em não perder tempo. Desta esta maneira o diálogo na família acaba sendo pouco exercitado (WAGNER et al, 2002).

Já quando se obtém a comunicação, esta se caracteriza por um aumento nos confrontos entre pais e filhos, ocorrendo em função do crescente questionamento do filho adolescente com relação às regras, valores e crenças familiares. Nesse sentido, a principal tarefa da família nesse momento evolutivo do adolescente é aumentar a flexibilidade das fronteiras familiares integrando os movimentos de independência dos filhos (WAGNER et al, 2005). Compete à família permitir que o adolescente prepare esta fase impulsionando a subjetividade forma 
saudável. Porém para exercer essa função, os pais precisam resolver a ambivalência sobre o crescimento dos filhos, largando o medo de perdê-los e os deixando florescer e crescer.

Sendo assim, os pais exercem o seu papel de educadores, baseados nos valores construídos, adotando mecanismos que colaboram com as suas formas de transmiti-los, munidos, principalmente, de interesse contínuo de cuidar dos filhos buscando compreender e respeitar a individualidade sem deixar de orientá-los (BARRETO E RABELLO, 2015).

O adolescente e seus familiares passam por inúmeras crises durante o curso da vida, mas o modo como elas serão enfrentadas é de extrema importância na formação do perfil do indivíduo no futuro e na sua maneira de lidar com determinadas situações de forma mais eficaz e assertiva.

O presente trabalho buscou identificar os estilos parentais de pais de adolescentes em tratamento psicológico em um Centro de Atenção Psicossocial do litoral norte do RS, bem como verificar de que forma os estilos parentais influenciam na comunicação parental e qual a percepção destes pais frente aos comportamentos de seus filhos.

\section{FUNDAMENTAÇÃO TEÓRICA}

\subsection{A família}

A família é definida como uma instituição que se organiza socialmente, dentro da qual está vinculado o ser humano através do nascimento, casamento e filiação, de acordo com os costumes, configurações políticas do Estado e da cultura da época onde está integrada, sendo vista como o agrupamento de pessoas que se unem parentalmente ou através de relação conjugal impregnada de propósitos comuns e afetividade, possibilitando ao indivíduo um desenvolvimento subjetivo (MALUF, 2010).

$\mathrm{Na}$ ótica antropológica, a função de unir um homem e uma mulher com sua procriação apresenta a família como um fenômeno universal que está inserido nas diversas sociedades (ROUDINESCO, 2003). Porém, a estrutura familiar se modifica conforme a evolução histórica, incluindo as variáveis econômicas, religiosas ou sociopolíticas de cada época, além de assegurar a sobrevivência da espécie, promover o desenvolvimento psicossocial. Desse modo, a família vem se constituindo como pequeno grupo social, no qual estão inseridas 
diversas relações conjugais e ou parentais aliadas ao compromisso, afeto e partilha entre seus membros (BARRETO E RABELLO, 2015).

Nas sociedades primitivas, o instinto sexual foi à base da formação dos primeiros grupos sociais sem a preocupação da finalidade da união. Contudo, com a existência da prole e o crescimento da cultura, criou-se uma organização social para garantir ao indivíduo a capacidade de ser funcional e saudável. No governo romano, a família se apresentava como uma composição social organizada, cujos membros eram unidos na submissão ao chefe (o pai) que exercia completos poderes de controlar a vida dos filhos (independente da idade) em relação ao casamento, ao divórcio, aos bens, podendo vender ou abandoná-los. Todavia, na idade média, essa situação começou a mudar com a influência do Cristianismo através de uma nova compreensão de moral que tornava a figura do pai mais humana, sendo a representação da igreja predominadora na formulação de novas bases sobre a família, tornando sagrada a união matrimonial (MALUF, 2010).

Na modernidade, com o surgimento da indústria, a família teve que se adequar à nova realidade de produção de trabalho, levando os pais, dentro da família nuclear, a se dividirem nas tarefas e, consequentemente, diminuir o cuidado com a educação dos filhos. $\mathrm{Na}$ contemporaneidade, por sua vez, a família ocidental ainda se apresenta como o agrupamento humano organizado mais sólido da sociedade, mesmo não sendo mais submetida a diversos segmentos sociais. Demonstra se estabelecer cada vez mais organizada como pequeno grupo que através do apoio econômico, físico, social e afetivo oferecidos aos seus membros, busca promover uma estabilidade social como um núcleo que se propaga continuamente (ZAMBERLAM, 2001).

Devido à mudança de costumes, a família vem priorizando o afeto como um apoio que tem o objetivo de valorizar o ser humano em sua dignidade e subjetividade. Por isso, a contemporaneidade se apresenta, conforme a Constituição Federal e o Código Civil, como a época mais preparada para manter as diversas modalidades de família, assim como novas configurações que já vem sendo legisladas em vários países como a família homoafetiva e outras (MALUF, 2010).

Entretanto, com o favorecimento da liberdade de escolhas, das livres relações de afeto dentro das diversas estruturações, surgiram, também, desequilíbrios em determinadas relações, no que se refere à parento-filial, a família vista no passado com grande autoritarismo 
cedeu o seu espaço à família em desordem no presente, cujos conflitos íntimos extinguem a imagem, principalmente, do pai autoritário, desvelando um ser na sua individualização (BARRETO E RABELO, 2015).

Na sociedade, cada membro ou grupo nela inserido, necessita assumir uma função que lhe atribua a importância de sua participação e permanência nessa esfera, nesse aspecto, as funções biológica e psicossocial da família estão fortemente ligadas, visto que o objetivo de proteger e conservar colabora na construção de subjetividade em cada pessoa que se vincula, originando todo o processo de cultura (ZAMBERLAM, 2001).

Desse modo, a função social da família consiste na proteção dos seus membros, fornecendo afeto e segurança e contribuindo para o desenvolvimento da subjetividade, conforme o período histórico onde se encontra, com o propósito de aprender a interagir no meio social estruturando o indivíduo na sua formação e socialização (MALUF, 2010).

\subsection{A adolescência e suas características}

Consideram-se adolescentes para os efeitos da lei o indivíduo entre doze e dezoito anos de acordo com o Estatuto da criança e do adolescente - ECA (BRASIL, 1990). Suas características são decorrentes do "amadurecer"; são hormônios jogados na circulação sanguínea e o desabrochar da sexualidade os fatores responsáveis pelo aparecimento da sintomatologia da adolescência normal. A adolescência se refere, a um período de latência social constituída no ingresso do mercado de trabalho e extensão do período escolar, da necessidade do preparo técnico. Estas características não são tomadas aqui como naturais e sim, constituídas no processo histórico e social: crises de identidade e busca de si mesmo; tendência grupal; necessidade de intelectualizar e fantasiar; atitude rebelde; onipotência e outras. As condições sociais nas quais se encontram os jovens são como fonte mobilizadora e geradora da chamada "adolescência". A sociedade reconhece, então, uma fase do desenvolvimento de seus filhos e jovens e atribui-lhe significados; espera algumas condutas de seus filhos e jovens. Os jovens que não possuíam referências claras para seus comportamentos utilizam, agora, essas características como fonte adequada de suas identidades: são agora adolescentes (BOCK, 2007). 
Assim mostra-se a adolescência, recusada num limbo, acabando interpretando e encenando o catálogo dos sonhos adultos, com maior ou menor sucesso. Mas, através de todas as suas variantes, ela sempre encarna o maior sonho de nossa cultura, o sonho de liberdade. Desta forma, por tenta0r dispensar a tutela dos adultos, a rebeldia adolescente se torna uma encenação do ideal cultural básico; as condutas adolescentes em todas as suas incertezas se cristalizam, se fixam e se tornam objetos de imitação. Tudo leva a fazer da adolescência um ideal social (CALLIGARIS, 2009).

Portanto, o adolescente assume significações instituídas da sociedade contemporânea, na qual busca o direito pela construção da individualidade, da possibilidade de escolher e de liberdade, influenciando na construção da sua subjetividade. Assim, pode ser visto como um ser em meio às relações socioculturais, edificando um mundo subjetivo que necessita do apoio constante e equilibrado daqueles que, vinculados nesse processo existencial, têm a função de orientá-los (BARRETO E RABELO, 2015).

\subsection{O adolescente e os estilos parentais}

Diana Baumrind em 1966 começou o estudo sobre estilos parentais para avaliar o impacto destas práticas na vida do indivíduo. A autora utiliza uma abordagem configuracional para definir os estilos parentais, argumentando que um determinado aspecto do comportamento parental é dependente da configuração de todos os outros aspectos (BRÁS, 2008).

Os pais do tipo permissivo não exercem controle e não encorajam a obediência a padrões externos. Estes pais não se apresentam como agente ativo da modificação de comportamento dos filhos, ou como um modelo, mas sim como um recurso que estes podem utilizar. As principais características deste estilo são a ausência de normas e regras; a elevada tolerância e aceitação dos impulsos das crianças; o fornecimento excessivo de ajuda e de padrões irrealisticamente baixos; a pouca estimulação da criança; os baixos níveis de exigência que revelam falta de autocontrolo e de autoconfiança podem levar os filhos a sentirem-se excessivamente dependentes e superprotegidos. Os pais permissivos, apesar de 
não fazerem uso correto do poder, podem tornar-se violentos quando perdem o controlo da situação (BAUMRIND, 1966).

Já os pais autoritários, utilizam do controle para modelar o comportamento dos filhos de acordo com os seus padrões de conduta, absolutos e intransigentes. Estes pais valorizam o respeito pela autoridade e pela ordem, as suas medidas de obediência são punitivas e não encorajam a troca de opiniões com os seus filhos, acreditando que devem aceitar a palavra dos pais como aquilo que está certo. As principais características deste estilo são as exigências excessivas, a supressão de conflito, a recusa em ajudar, a monopolização do poder de decisão e a valorização excessiva das regras e das normas (BAUMRIND, 1966).

Os pais autoritativos exercem um controlo firme, mas de forma racional; valorizam tanto a obediência como a autonomia, o que faz com que exerçam um controle consistente quando há divergências, mas não imponham restrições excessivas não recorrendo a práticas punitivas exageradas, como no estilo autoritário. Estes pais encorajam a troca de ideias e quando a criança se recusa a obedecer, solicitam que a criança lhe explique a razão do seu não conformismo. Esse estilo favorece a internalização das normas parentais, tendo em conta que a interação verbal é encorajada e os pais explicam as razões inerentes às regras e decisões. As principais características dos pais autoritativos são a exigência e o fornecimento de autonomia em níveis intermédios, a estimulação da comunicação verbal, o uso do poder, mas não de forma punitiva e sim para chamar as crianças/jovens à razão, a responsividade, na medida em que são afetuosos e empenhados cognitivamente, proporcionam um ambiente estimulador e desafiante aos filhos (BAUMRIND, 1966).

Em outro polo, trazemos os pais com estilo negligente, sendo aqueles que não exigem responsabilidade dos filhos, mas também não encorajam a sua independência. São pais frios, inacessíveis, indiferentes, centrados neles próprios, não dando à criança/jovem os estímulos afetivos de que necessita e recorrem a castigos ou pressões para evitar que o filho perturbe o seu comodismo. Os filhos têm a tendência de serem tristes, frustrados, inseguros, desorientados, podendo mais facilmente ter problemas de conduta, como a delinquência (BAUMRIND, 1989).

Baumrind e outros estudiosos revelam também que o estilo autoritativo é aquele que gera filhos com melhores níveis de ajustamento psicológico e comportamental, mais competentes e confiantes nas suas capacidades, submetendo-se menos em problemas. Apesar 
de este ser considerado o estilo mais adaptativo, existem fatores culturais que podem determinar os efeitos dos diferentes estilos parentais (BRÁS, 2008).

As habilidades sociais educativas são de suma importância para as práticas parentais assertivas, sendo elas: Observar, escutar, interpretar comportamentos, iniciar e manter conversação com os filhos, adequar a própria fala à compreensão do filho, expressar amor, afeto e agrado aos filhos, defender os próprios direitos em relação aos filhos, incentivar a emissão adequada de comportamentos pelos filhos, dar feedback ao comportamento emitido, controlar as próprias emoções, verbalizar e aplicar conceitos de assertividade, não assertividade e agressividade, solicitar favores, recusar pedidos não razoáveis dos filhos, expressar as próprias opiniões, inclusive as de desagrado, dar ordens curtas e claras, pedir mudança no comportamento dos filhos, lidar com críticas recebidas pelos filhos, respeitar opiniões e direitos dos mesmos, e desculpar-se (BOLSANI-SILVA E MATURANO, 2002).

Em estudos de Bolsoni-Silva e Loureiro (2011) compararam práticas educativas parentais e comportamento de crianças distribuídas em dois grupos (clínico, com problemas de comportamento e não clínico, sem problemas de comportamento) tendo, como fonte de informações, os relatos das mães. Os resultados demonstraram que no grupo não clínico as mães apresentaram-se mais comunicativas e afetuosas, e filhos com maior variabilidade de habilidades sociais, evidenciando que esse relacionamento positivo favorece a alcance de obediência por parte da criança quando as mães necessitam estabelecer limites, diferentemente do grupo clínico, no qual as mães relataram menos obediência por parte de seus filhos (PARDO E CARVALHO, 2012).

De acordo com esses estudos, foi implementado em alguns serviços de psicologia aplicada o grupo de orientação a pais, funcionando com uma programação semanal de oito encontros, com duração de uma hora cada um deles, nos quais se busca fazer um levantamento dos problemas e temas de interesse para serem discutidos e trabalhados. Sempre que o problema se refere ao comportamento da criança, os pais são solicitados a realizarem observações em casa e trazerem relatos sobre esses comportamentos, seja no ambiente de casa ou em outros espaços. Tais exemplos são apresentados e discutidos pelo grupo no encontro seguinte, estimulando-se a troca de experiências os pais. Desse modo, os pais vão revendo suas formas de pensar e de agir com os filhos a partir de informações derivadas de pessoas que estão em situações semelhantes às delas (PARDO E CARVALHO, 2012). 


\subsection{Os vínculos afetivos parentais}

O vínculo com os pais já foi implementado na literatura como um fator estruturante da personalidade. Bowlby (1997) defendeu a tese de que existe uma relação muito estreita entre as experiências da criança com seus pais e sua capacidade futura para estabelecer vínculos afetivos, e que essa relação tem também repercussões significativas do ponto de vista da psicopatologia. Assim, a qualidade dos vínculos que puderam ser constituídos pelas crianças, bem como dos modelos representacionais que lhes correspondem, pode se constituir como importante fator de resiliência no enfrentamento das crises do ciclo vital, incluindo a adolescência (SCHNEIDER, et al 2007)

Desta forma, relações saudáveis do ponto de vista emocional funcionam como fatores de proteção. A qualidade das relações interpessoais e suas representações afetivas desempenham, portanto, um papel essencial na determinação de vulnerabilidades a psicopatologias e na promoção de segurança e ajustamento psicossocial. Em contrapartida, vínculos inseguros, desorganizados e indiscriminados mostram-se relacionados ao sofrimento psíquico dos adolescentes, expondo-os a situações de vulnerabilidade emocional e afetiva (JORDÃO, 2010).

Para que os pais possam propiciar apoio para o desenvolvimento se seu filho, é necessário que eles estejam atentos à qualidade desses vínculos, sem que haja a necessidade de alcançar a perfeição - o que socialmente se acredita que seja perfeito -, e sim algo particular, de família para família, que faça sentido para as pessoas envolvidas. Atender as expectativas de viver intensamente a vida pessoal, profissional e conjugal, inclusive na relação com os filhos, causa uma sensação de desgaste aos genitores. Os pais precisam estar presentes de forma suficientemente boa, o que significa atender o que for necessário aos filhos, mas também deixar que suas próprias falhas sejam sentidas não como uma incapacidade, mas sim como parte do que é humano, para que seus filhos também possam errar sem medo, agir espontaneamente no mundo e alcançar sua própria identidade (ANDRADE, et al 2012). 
Portanto, o presente estudo visa compreender os estilos parentais e criar oportunidades que abram espaço para o diálogo entre pais e filhos, salientando a importância do papel parental na educação dos filhos apresentando esses estilos como uma gama de atitudes face à criança e obtendo maneiras mais assertivas de lidar com umas das fases mais temidas pelos pais, a adolescência.

\section{METODOLOGIA}

\subsection{Delineamento}

Pesquisa qualitativa, do tipo exploratória. As pesquisas desse tipo apresentam maior familiaridade com o problema de pesquisa. Visa a análise de dados bibliográficos, entrevista direta com pessoas que partilham de experiências associadas ao problema de pesquisa do projeto e também análise de padrões que visam à compreensão dos objetivos bem como, aplicar questionários ou administrar testes (GUNTHER, 2006).

\subsection{Participantes}

Participaram deste estudo seis pais de adolescentes, de ambos os sexos, com faixa etária de 32 a 46 anos com os filhos em tratamento psicológico de no mínimo um mês em um Centro de Atenção Psicossocial- CAPS do Litoral Norte do RS. Desta forma, a amostragem foi feita por conveniência.

\subsection{Instrumentos de coleta de dados}

Os instrumentos utilizados para a coleta de dados foram o questionário sociodemográfico, entrevista semiestruturada, e inventário de estilos parentais.

\subsubsection{Questionário Sociodemográfico}


Foi utilizado um questionário estruturado para coletar informações acerca do perfil sociodemográfico dos participantes da pesquisa.

\subsubsection{Entrevista semiestruturada}

As entrevistas foram baseadas em perguntas semi estruturadas guiadas por relação e pontos de interesse, permitindo aos entrevistados expressar o entendimento em suas próprias palavras, abordando os seguintes focos: Motivo da procura ao tratamento, dificuldades referentes à adolescência, comunicação e limites, convívio familiar e as implicações no comportamento dos adolescentes e disposição dos pais frente a mudanças nas práticas parentais.

\subsubsection{Inventário de Estilos Parentais}

O Inventário de Estilos Parentais - IEP consiste em apresentar como certas práticas utilizadas pelos pais na educação dos filhos podem acarretar, por um lado, o desenvolvimento de comportamentos antissociais e, por outro, o desenvolvimento de comportamentos pró-sociais de crianças e adolescente. Este deriva de um modelo teórico composto por sete práticas educativas, sendo duas consideradas positivas (monitoria positiva e comportamento moral) e cinco negativas (abuso físico, disciplina relaxada, monitoria negativa, negligência e punição inconsistente). Este consistirá nas respostas de 42 questões, sendo que cada uma consta de uma frase à qual a os pais deverão responder indicando a frequência com que age (ia) conforme a situação descrita na frase. Assim, responde-se: NUNCA se em 10 ocasiões, ele (a) agiu daquela forma de 0 a 2 vezes, ÀS VEZES se em 10 ocasiões, ele (a) agiu daquela forma de 3 a 7 vezes ou SEMPRE se em 10 ocasiões, ele (a) agiu daquela forma de 8 a 10 vezes.

Tabela 1 - Interpretação dos resultados IEP.

\begin{tabular}{|l|l|}
\hline PERCENTUAIS DO IEP & INTERPRETAÇÃO DOS RESULTADOS \\
\hline De $80 \%$ a $99 \%$ & $\begin{array}{l}\text { Estilo Parental Ótimo, com presença marcante das } \\
\text { práticas parentais positivas e ausência das práticas } \\
\text { negativas. }\end{array}$ \\
\hline De $55 \%$ a $75 \%$ & $\begin{array}{l}\text { Estilo Parental Bom, acima da média, porém } \\
\text { aconselha-se a leitura de livros de orientação para pais } \\
\text { para aprimoramento das práticas parentais. }\end{array}$ \\
\hline
\end{tabular}




\begin{tabular}{|l|l|}
\hline De $30 \%$ a $50 \%$ & $\begin{array}{l}\text { Estilo Parental Regular, porém abaixo da média. } \\
\text { Aconselha-se a participação de grupos de orientação a } \\
\text { pais. }\end{array}$ \\
\hline De $1 \%$ a $25 \%$ & $\begin{array}{l}\text { Estilo Parental de Risco. Aconselha-se a participação } \\
\text { em programas de intervenção terapêutica, em grupo, } \\
\text { de casal ou individualmente, especialmente } \\
\text { desenvolvidos para pais com dificuldade em práticas } \\
\text { educativas nas quais possam ser enfocadas as } \\
\text { consequências do uso de práticas negativas em } \\
\text { detrimento das positivas. }\end{array}$ \\
\hline
\end{tabular}

Fonte: Inventário de Estilos Parentais (IEP) - GOMIDE, 2006.

\subsection{Procedimentos da coleta de dados}

No primeiro momento, entrou-se em contato com o CAPS para verificar a viabilidade de realizar a pesquisa neste local. Após, a pesquisa foi submetida no comitê de ética do Centro Universitário Cenecista de Osório- UNICNEC, e mediante aprovação foi apresentada formalmente para a coordenação do local. Em seguida, a coleta de dados foi agendada através de ligação telefônica, verificando dia e horário de acordo com a disponibilidade de cada participante. Aconteceu em um CAPS do Litoral Norte do RS com tempo mínimo de uma hora. A aplicação dos instrumentos foi realizada após a explicação do Termo de Consentimento Livre e Esclarecido - TCLE e mediante aceitação do participante, ocorreu a aplicação da ficha sociodemográfica, a entrevista semiestruturada, devidamente gravada, e por fim a aplicação do Inventário de Estilos Parentais - IEP.

\subsection{Análise dos dados}

A análise dos dados da entrevista semiestruturada foi realizada pelo método de Bardin (1977), na qual a análise de conteúdo reuniu um conjunto de técnicas de organizações e informações. Trata-se de uma ferramenta metodológica usada junto aos dados qualitativos para revelar temas, tópicos e conhecimentos, considerando o discurso humano, falado e escrito (CAMPOS \& TURATO, 2009). Os resultados do inventário foram levantados a partir 
dos critérios de correção do manual (2006) e posteriormente analisados juntamente com os demais instrumentos.

\subsection{Considerações éticas}

A pesquisa foi submetida ao Comitê de Ética em Pesquisa com Seres Humanos- CEP do Centro Universitário Cenecista de Osório mediante parecer consubstanciado $\mathrm{n}^{\mathrm{o}}$ : 3.684.960.

Todos os participantes foram informados a respeito dos objetivos da pesquisa assinaram o Termo de Consentimento Livre e Esclarecido. Todos os nomes envolvidos na análise dos dados serão utilizados de forma fictícia, preservando os dados do participante. Esta pesquisa respeitou e seguiu os critérios éticos de acordo com as resoluções 196/96 que aborda questões éticas em pesquisa com seres humanos, não apresentando riscos aos participantes.

A presente resolução se fundamenta nos principais documentos internacionais sobre pesquisas que envolvem seres humanos, a saber, o Código de Nuremberg de 1947, a Declaração Universal dos Direitos Humanos de 1948, a Declaração sobre Bioética e Direitos Humanos, de 2005, e outros documentos afins. Cumpre as disposições da Constituição da República Federativa do Brasil de 1988 e da legislação brasileira correspondente. Esta Resolução aciona, sob a ótica do indivíduo e das coletividades, os referenciais da bioética, autonomia, não maleficência, beneficência, justiça e equidade, dentre outros, e visa a assegurar os direitos e deveres que dizem respeito aos participantes da pesquisa, à comunidade científica e ao Estado. O caráter contextual das considerações aqui desenvolvidas implica revisões periódicas desta Resolução, conforme necessidades nas áreas tecnocientífica e ética (BRASIL, 2012).

\section{RESULTADOS}

$\mathrm{Na}$ tabela 2 serão apresentados os resultados obtidos através do questionário sociodemográfico que caracteriza os participantes desta pesquisa.

Tabela 2 - Dados Sociodemográficos. 


\begin{tabular}{|c|c|c|c|c|c|c|}
\hline & $\mathbf{P 1}$ & $\mathbf{P 2}$ & $\mathbf{P 3}$ & P4 & P5 & P6 \\
\hline Idade & 36 & 38 & 39 & 44 & 32 & 46 \\
\hline Sexo & Fem. & Fem. & Fem. & Fem. & Fem. & Mas. \\
\hline Escolaridade & Fund. Com. & $\begin{array}{l}\text { Ens.Médio } \\
\text { Completo }\end{array}$ & $\begin{array}{l}\text { Superior } \\
\text { Incomp. }\end{array}$ & $\begin{array}{l}\text { Superior } \\
\text { Incomp. }\end{array}$ & $\begin{array}{l}\text { Fund. } \\
\text { Incomp. }\end{array}$ & $\begin{array}{l}\text { Ens. Médio } \\
\text { Incomp. }\end{array}$ \\
\hline Estado Civil & Solteira & Casada & Casada & Viúva & Casada & Casado \\
\hline Ocupação & Desempregada & Desempregada & Estudante & Aposentada & Assalariada & $\begin{array}{l}\text { Estudante/ } \\
\text { Autônomo }\end{array}$ \\
\hline $\mathbf{N}^{\circ}$ de filhos & 4 & 3 & 2 & 2 & 1 & 2 \\
\hline $\begin{array}{l}\text { Idade e sexo do } \\
\text { filho } \\
\text { adolescente }\end{array}$ & Fem. 12 & Masc. 14 & Masc. 13 & Fem. 17 & Masc. 14 & Fem. 14 \\
\hline $\begin{array}{l}N^{\circ} \text { de cômodos } \\
\text { na casa }\end{array}$ & 5 & 7 & 11 & 6 & 8 & 6 \\
\hline $\begin{array}{l}N^{\circ} \text { de pessoas } \\
\text { na casa }\end{array}$ & 3 & 6 & 4 & 3 & 3 & 4 \\
\hline Renda Mensal & 260,00 & $1.800,00$ & $5.000,00$ & $5.000,00$ & $3.700,00$ & $2.000,00$ \\
\hline
\end{tabular}

Fonte: Elaborada pela autora, 2019.

De acordo com os dados obtidos na Tabela 2 podemos observar que a pesquisa foi realizada com participantes com idade entre 32 e 46 anos, dos seis, um é do sexo masculino, restante feminino, sendo que a escolaridade varia desde o ensino fundamental incompleto até ensino superior incompleto. Quanto ao estado civil, um participante é solteiro, com 04 filhos, três são casados com 03, 02 e 01 filho respectivamente, e uma viúva, com 02 filhos. Dos quatro entrevistados, a idade dos filhos adolescentes varia de 12 a 17 anos e a renda mensal familiar de $\mathrm{R} \$ 260,00$ a $\mathrm{R} \$ 5.000,00$.

Tabela 3 - Resultados do Inventário de Estilos Parentais - IEP.

\begin{tabular}{|l|l|r|}
\hline PARTICIPANTE & $\begin{array}{l}\text { INDICE DE ESTILOS } \\
\text { PARENTAIS }\end{array}$ & PONTUAÇÃO \\
\hline P1 & Estilo Parental de Risco & $-14(1 \%$ a 25\%) \\
\hline P2 & Estilo Parental de Risco & $-7(1 \%$ a 25\%) \\
\hline P3 & Estilo parental Bom & $10(55 \%$ a $75 \%)$ \\
\hline P4 & Estilo Parental Ótimo & $11(80 \%$ a 99\%) \\
\hline P5 & Estilo Parental de Risco & $-4(1 \%$ a 25\%) \\
\hline P6 & Estilo Parental Ótimo & $17(80 \%$ a 99\%) \\
\hline
\end{tabular}

Fonte: Elaborada pela autora, 2019.

Diante os dados obtidos do Inventário de Estilos Parentais apresentados na tabela 3, podemos constatar que índice das práticas parentais variou entre Estilo Parental de Risco, Estilo Parental Bom e Estilo Parental Ótimo. Sendo que P1, P2 e P5 apresentaram Estilo 
Parental de Risco (pontuação entre -14 e -4), P3 apresenta Estilo Parental Bom (pontuação 10) e P4 e P6 Estilo Parental Ótimo (pontuação entre 11 e 17). Para a análise das entrevistas foi utilizado o método de análise de conteúdo de Bardin (1977) sendo criadas as seguintes categorias:

Categoria Motivo da Procura ao CAPS: Nesta categoria analisamos a história do participante referente ao motivo de ter buscado tratamento para seu filho.

\section{Quadro 1}

\begin{tabular}{|l|l|}
\hline $\mathbf{P 1}$ & $\begin{array}{l}\text { "Pelo que ela passou... Ela sofreu na verdade um abuso e ai então ela nunca tinha apresentado } \\
\text { problema nenhum, ela superou bem, mas ai de uns tempos pra cá ela começou a ter crise de } \\
\text { ansiedade. Foi onde que procurei aqui pra ajudar há uns três meses. }\end{array}$ \\
\hline $\mathbf{P 2}$ & $\begin{array}{l}\text { "É o comportamento dele, ele é muito agitado. Já está vindo ao CAPS em torno de um mês. Mas ele } \\
\text { não é hiperativo, ele sabe o que ele faz, só é muito agitado. Na escola também, ele já é repetente } \\
\text { dois anos (...)." (sic). }\end{array}$ \\
\hline P3 & $\begin{array}{l}\text { "Pelo medo de dormir... A princípio pelo medo de dormir, na primeira vez que procurei tratamento, } \\
\text { há dois anos, ele melhorou. Aí o colocamos pra fazer várias coisas, natação, futebol, para quando } \\
\text { chegasse em casa tivesse sono e não ter "tempo" para sentir esse medo... Só que agora (está vindo } \\
\text { ao tratamento há dois meses) ele voltou a ter esse medo (...). Ele diz que tem pensamentos com o } \\
\text { "diabo", que ele vai fazer mal as pessoas que ele gosta, a familia, amigos (...)" (sic). }\end{array}$ \\
\hline $\mathbf{P 4}$ & $\begin{array}{l}\text { "Por conta do falecimento do pai, ela entrou em depressão. Ela está frequentando o CAPS há uns } \\
\text { três anos e meio já" (sic). }\end{array}$ \\
\hline P5 & $\begin{array}{l}\text { "Porque não estava indo para a escola, eu tive que levar no conselho tutelar, tive que partir para } \\
\text { esse lado, porque ele não estava estudando, e quando brigamos eu fui dar uma "chinelada" nele e } \\
\text { ele me retribuiu com um saco no braço (...) Agora ele está melhor comigo, porque a conselheira } \\
\text { conversou com ele, que não pode brigar comigo, nem faltar à escola (...)" (sic). }\end{array}$ \\
\hline P6 & $\begin{array}{l}\text { "Nós fomos indicados pela escola, ela teve problemas lá, a respeito de Bullying, ela é uma guria } \\
\text { que presta atenção em tudo (...) se liga muito nas coisas, só que criança em escola fica fazendo } \\
\text { comentários, e ela pega tudo aquilo para ela (...). Na antiga escola, a diretora conversou com a a } \\
\text { gente e falou para ligar para o CAPS para agendar um acolhimento, ela já está vindo há uns três } \\
\text { meses" (sic). }\end{array}$ \\
\hline
\end{tabular}

Fonte: Elaborado pela autora, 2019.

Categoria Representação da Adolescência pelos pais: Nesta categoria apresentamos como o participante caracteriza a adolescência em geral.

\section{Quadro 2}

\begin{tabular}{|l|l|}
\hline P1 & $\begin{array}{l}\text { "Complicada. Eu não tenho experiência com adolescência. Tenho outros filhos adultos, só que eu } \\
\text { não tenho experiência com adolescentes. Quando me separei do pai deles, eles ficaram com a } \\
\text { família do pai (...)" (sic). }\end{array}$ \\
\hline P2 & $\begin{array}{l}\text { "Uma fase muito bonita, mas bem complicada, porque é muito difícil colocar limites, e ele tem as } \\
\text { estratégias dele, de enrolar (risos), bem complicado." (sic). }\end{array}$ \\
\hline
\end{tabular}




\begin{tabular}{|l|l|}
\hline P3 & $\begin{array}{l}\text { "É bem tranquilo, sabe?! Não tive problema de espécie alguma, nem com escola, nem com ninguém } \\
(. .) \text { ". }\end{array}$ \\
\hline P4 & $\begin{array}{l}\text { "Eu vejo a adolescência hoje bem diferente do meu tempo. Os adolescentes de hoje estão muito } \\
\text { avoados. Na minha época não tinha essa conectividade, era mais olho no olho, as amizades cada } \\
\text { um ia à casa um do outro, tinha conversas, reuniões (...). Antes se conhecia mais a essência das } \\
\text { pessoas. As emoções, o que sentiam, hoje não, não se sabe em uma conversa online o que a pessoa } \\
\text { está realmente sentindo" (sic). }\end{array}$ \\
\hline P5 & "É complicado. Meu filho diz que não mando nele, que ele manda em si (...)" (sic). \\
\hline P6 & $\begin{array}{l}\text { Olha, para mim é igual na minha época. As mesmas reclamações que a gente fazia, são as que eles } \\
\text { fazem agora (...)". }\end{array}$ \\
\hline
\end{tabular}

Fonte: Elaborado pela autora, 2019.

\section{Categoria Características Comportamentais dos Filhos Adolescentes: Nesta categoria} apresentamos como os pais veem seus filhos em características comportamentais.

\section{Quadro 3}

\begin{tabular}{|c|c|}
\hline P1 & $\begin{array}{l}\text { "Tem dias que ela é bem nervosa, tem dias que não, que está bem tranquila, (...) ela oscila } \\
\text { bastante. Mas no geral, ela é uma menina boa, não tenho queixas, mas sim em como lidar com ela, } \\
\text { nessa oscilação dela, que é difícil (...). Nos estudos ela é muito boa, é estudiosa, aprende fácil as } \\
\text { coisas (...)" (sic). }\end{array}$ \\
\hline P2 & $\begin{array}{l}\text { "Ele é agitado, ele não conversa, ele grita (...). Em casa é muito de ajudar... Na escola se tem } \\
\text { algum problema, ele se mete... Quando o assunto não é com ele, ele quer ajudar (...). Ele é muito } \\
\text { assim, quer estar dentro dos assuntos. Ele é muito agitado nesse sentido, mas ele é muito } \\
\text { inteligente, não sei porque ele está patinando no colégio" (sic). }\end{array}$ \\
\hline P3 & $\begin{array}{l}\text { "Uma criança que tem responsabilidade, que tem compromisso, até demais. É uma criança muito } \\
\text { ansiosa, porque se ele tem um trabalho pra entregar na escola semana que vem, ele já tá essa } \\
\text { semana com o trabalho não digo concluído, mas em processo. Ele é tudo muito "além”. Não tenho } \\
\text { o que dizer, é responsável com as tarefas dele, não preciso mandar (...)” (sic). Não tenho o que } \\
\text { dizer sobre ele, não vejo rebeldia, nem falta de limites. Ele é muito prático, na escola, quando } \\
\text { busco as notas, os professores tem prazer de falar dele" (sic). }\end{array}$ \\
\hline P4 & $\begin{array}{l}\text { "Ela sempre foi uma menina muito meiga e carinhosa, tranquila, um pouco tímida, só que depois } \\
\text { que ela teve a depressão, oscila muito, tem momento de irritabilidade, fica muito braba, mas em } \\
\text { seguida já volta, acho que ela reflete e volta ao estado normal. Mas não bato mais de frente, era } \\
\text { muito desgastante, porque eu perdia razão gritando, porque ela tem o dom da palavra e eu não } \\
\text { tenho, então acabava perdendo nas discussões por só ficar gritando, (...) mudei a tática, discuto } \\
\text { com ela dando o meu silêncio, e ela acaba repensando. Então agora aprendi a lidar com ela (...). } \\
\text { Fica tranquilo, um ambiente saudável” (sic). }\end{array}$ \\
\hline P5 & $\begin{array}{l}\text { "Ele é assim, hiperativo, agitado. Hoje ele está bem, amanhã já está explosivo, é sempre assim. Não } \\
\text { aceita não, (...) não tem limites, ele xinga, depois volta ao normal, dando beijo, abraço, só que } \\
\text { oscila muito. Ele quer atenção só pra ele (...)" (sic) }\end{array}$ \\
\hline P6 & $\begin{array}{l}\text { "Ela é tranquila, é uma guria muito especial, sou suspeito para falar, eu amo muito meus filhos. Só } \\
\text { que ela é quietinha, bem na dela, desde pequena, até acho que a gente pecou em não ter procurado } \\
\text { orientação antes, só que a gente achava normal (...)" (sic). }\end{array}$ \\
\hline
\end{tabular}

Fonte: Elaborado pela autora, 2019. 


\section{Categoria Dificuldades na criação dos filhos e Ajuda de outros: Nesta categoria os} participantes representam quais as dificuldades na educação de seus filhos e se possuem algum tipo de auxílio de Outros.

\section{Quadro 4}

\begin{tabular}{|c|c|}
\hline P1 & $\begin{array}{l}\text { "A dificuldade é mais em como lidar com essas oscilações dela, para não se machucar, das } \\
\text { ansiedades dela, de eu não conseguir fazer isso cessar. Mais isso, porque no resto é coisa normal. } \\
\dot{E} \text { só esse lado das oscilações, porque eu também sou "altos e baixos", então quando estão as } \\
\text { duas... é dificil (...)" (sic). }\end{array}$ \\
\hline P2 & $\begin{array}{l}\text { "Meu esposo ajuda, mas mais sou eu. E dificuldades, colocar limites, né?! O resto é tranquilo, da } \\
\text { adolescência eu até entendo, só estou sempre controlando ele, na rua, deixo os amiguinhos vir até } \\
\text { aqui, mas mais os estudos, porque eu queria que ele estivesse terminando" (sic). }\end{array}$ \\
\hline P3 & $\begin{array}{l}\text { "O pai ajuda. E dificuldade... Na educação dele, nada... é mais esse problema psicológico, é uma } \\
\text { situação completamente nova, não sabemos como agir. Quando ele me falou do medo dele, fiquei } \\
\text { com medo também, porque a gente não sabe até onde vai esse tipo de transtorno, por isso trouxe } \\
\text { ele" (sic). }\end{array}$ \\
\hline P4 & $\begin{array}{l}\text { "Olha, eu praticamente crio ela sozinha, desde que o pai faleceu (...). Sobre dificuldades, às vezes } \\
\text { sim, quando ela está oscilando de humor, quando não toma medicação. Então eu sentei com ela e } \\
\text { conversei numa boa sobre a medicação (...), depois que conversei com ela, ela fez uma caixinha } \\
\text { escrito "isso é muito importante pra mim" com o remédio dentro. Ai elogiei e disse que era muito } \\
\text { bom ela está pensando no bem dela. Então já vi que com o diálogo funciona muito mais com ela eu } \\
\text { consigo ganhar dela, porque antes eu gritava, esbravejava e não tinha efeito, só desgaste" (sic). }\end{array}$ \\
\hline P5 & $\begin{array}{l}\text { "Meu marido ajuda... Olha, ele é um pai muito presente para ele. A dificuldade é mais a questão } \\
\text { dele não aceitar não, e nem ter limites" (sic). }\end{array}$ \\
\hline P6 & $\begin{array}{l}\text { "Eu e minha esposa, e o CAPS agora ajuda. De dificuldade mesmo é mais a parte dela querer ir } \\
\text { para a escola, voltar a se socializar, com os colegas. Porque toda a vez que ela vai para a escola } \\
\text { acaba se sentindo mal, dá crise de ansiedade, dor no peito, pânico de ir (...)" (sic). }\end{array}$ \\
\hline
\end{tabular}

Fonte: Elaborado pela autora, 2019.

Categoria Comunicação e Limites: Nesta categoria analisamos se os pais conversam sobre tudo, ou se possuem assuntos mais restritos de diálogo, visto também a construção de limites diante seus filhos adolescentes.

\section{Quadro 5}

\begin{tabular}{|c|c|}
\hline P1 & $\begin{array}{l}\text { "Falamos sobre tudo, não tem meios termos la em casa (...). Não tenho travas na língua, eu falo } \\
\text { mesmo. E eu acho que não tem que ter mesmo. Tem que falar, tem que orientar (...). Ela até que } \\
\text { entende muito bem os limites, ela bate um "pezinho", mas não desobedece, ela não se atreve. Mas } \\
\text { não apanha! Se disser que ela não se atreve porque eu bato, é mentira. Nunca apanhou. Eu só } \\
\text { ameaço, às vezes, pra ver se faz algum efeito" (sic). }\end{array}$ \\
\hline P2 & $\begin{array}{l}\text { “(...) Eu explico tudo para ele, porque eu fui muito reprimida pela minha mãe, porque sou filha } \\
\text { unica, dou mais liberdade pra eles, pra algumas coisas, para outras não (...). Ele tenta não } \\
\text { obedecer, mas depois ele... Ele irrita, ele enfrenta, é meio agressivo com as palavras, mas depois } \\
\text { ele vai ter que aceitar, não adianta, ele é "de menor". Não consigo dar limites, mas consigo dizer } \\
\text { não... Coisas mais fáceis assim (...)” (sic). }\end{array}$ \\
\hline
\end{tabular}




\begin{tabular}{|c|c|}
\hline P3 & $\begin{array}{l}\text { “(...) Ele sabe que sou bem aberta para conversar e o pai também, nunca se opôs a nada que fosse } \\
\text { preciso, necessário para ele. Sobre dizer não: sempre, sempre, sempre. Ele tem regras (...). } \\
\text { Geralmente o não vem primeiro. Tipo "mãe, quero um celular”, "não, agora não dá, mas depois a } \\
\text { gente pesquisa e juntamos para comprar” (...). Ele entende sabe, quando ele pediu a gente não teve } \\
\text { condições, porque é uma fortuna, mas ele foi juntando, juntando, juntando, que conseguiu (...), a } \\
\text { gente tem que pedir, merecer, esperar e ganhar, sempre nessa ordem (...)" (sic). }\end{array}$ \\
\hline P4 & $\begin{array}{l}\text { "Conversamos sobre tudo, sempre teve muito diálogo, sempre fui muito aberta. Dou muito limite, } \\
\text { só parei de dizer tanto "não", estou mostrando mais pra ela os dois lados das situaçóes, os } \\
\text { caminhos... Tipo, "Não concordo com isso, mas se tu fizeres vai ter tal reação. É ação e reação. } \\
\text { Como ela já está com } 17 \text { anos, estou dando mais essa abertura, de mostrar os dois lados da } \\
\text { moeda" (sic). }\end{array}$ \\
\hline P5 & $\begin{array}{l}\text { "Conversamos primeiro eu e meu marido, entre nós, depois conversamos com ele e colocamos as } \\
\text { condições para ele, conforme dá, dependendo da situação (...). Sempre digo para ele, só basta o } \\
\text { respeito e me dizer onde tu andas, então a gente sempre tem uma conversa bem boa, o problema é } \\
\text { como eu disse, acontece algo com ele, ele desconta tudo em mim (...)" (sic). }\end{array}$ \\
\hline P6 & $\begin{array}{l}\text { "A gente conversa tranquilo. Sobre tudo. Eles já sabem, que quando digo "não" é "não". Eu sou } \\
\text { bem flexível, converso e tudo, só que a mãe deles diz não e depois volta atrás se incomoda muito } \\
\text { ela. Aí a gente já estabeleceu, que quando isso acontecer é para ela dizer para ir falar comigo" } \\
\text { (sic). }\end{array}$ \\
\hline
\end{tabular}

Fonte: Elaborado pela autora, 2019.

Categoria Ambiente Familiar e Tempo de Convívio: Nesta categoria analisamos como se estrutura o ambiente familiar e o tempo de convívio entre os pais e seus filhos.

\section{Quadro 6}

\begin{tabular}{|l|l|l|}
\hline P1 & "(..) Eu trabalhava na noite, sabe?! Eu a deixava na babá, como eu trabalhava de noite, eu viajava \\
& também, às vezes a semana inteira. Eu só a via nos finais de semana. O conselho tutelar bateu \\
& nessa casa (...). Ela ficou um ano no abrigo. Ai então mais isso, quando ela saiu do abrigo, ficou \\
& com a minha mãe. Foi mais rápido passar para minha mãe (...). Depois ficou comigo (...). Agora \\
& que ela está comigo, geralmente a gente olha TV todos juntos, "socados" na minha cama, porque é \\
& a única TV que tem na casa. Às vezes eu fico um pouco mais retraída, porque também tenho meus \\
& problemas... Pra não falar nada, nem me estressar com eles, eu me retiro um pouco (...). Se eu não \\
& tiver que sair, passo o tempo todo com ela (...)" (sic).
\end{tabular}




\begin{tabular}{|l|l|}
\hline & $\begin{array}{l}\text { se metem, às vezes o mais velho me defende (risos) já ela não puxa para nenhum lado, diz que eu e } \\
\text { mãe dela estamos errados. Ela não é uma guria que gosta de atritos, não gosta de brigas. A gente } \\
\text { passa o dia todo por perto, menos quando ela está na escola. Tenho o serviço em casa, mas pouco } \\
\text { ela se mistura com gente, gosta mais de ficar no canto dela..." (sic). }\end{array}$ \\
\hline
\end{tabular}
Fonte: Elaborado pela autora, 2019.

\section{Categoria Convívio Familiar e Implicações no Comportamento do adolescente: Nesta} categoria relatamos a opinião dos pais sobre como o convívio familiar interfere nos comportamentos de seus filhos.

\section{Quadro 7}

\begin{tabular}{|c|c|}
\hline P1 & $\begin{array}{l}\text { "Interfere bastante, porque quando eu estou mais "atacada" eu já não consigo tratar bem, e o que } \\
\text { acontece, eu não judio, nem bato... Mas também não trato bem... E ela é muito melosa, e eu não sou } \\
\text { assim, sei que ela quer estar abraçada, agarrada, eu tenho aflição com isso... De uns tempos pra cá } \\
\text { eu estou assim, até tomo medicação (...). Só que às vezes eu não estou bem, tem as questões } \\
\text { financeiras, tu viu nossa renda, é muito baixa, não tem como não ficar estressada" (sic). }\end{array}$ \\
\hline P2 & $\begin{array}{l}\text { "O convívio familiar intervém bastante, porque quando a mãe e o pai estavam presentes, eles } \\
\text { interferiam um pouquinho, e muitas vezes eu deixava, só que em outras eu dizia que não é bem } \\
\text { assim... Só que tinha situações que era bom às interferências deles. Só que agora ficou um pouco } \\
\text { ruim de eles verem a avó naquela situação e perderam o avô. Então interfere no emocional dele, } \\
\text { ver tudo isso" (sic). }\end{array}$ \\
\hline P3 & $\begin{array}{l}\text { "(...) Acho que o que vem de casa vai para a vida toda. A gente cria os filhos, sabendo que depois } \\
\text { que casam, mudam a dinâmica deles, mas acredito que a essência, o caráter a responsabilidade é a } \\
\text { mesma, não muda" (sic). }\end{array}$ \\
\hline P4 & $\begin{array}{l}\text { "Reflete. A gente é um espelho para os filhos, apesar de que muitos filhos fazem o oposto dos pais, } \\
\text { por exemplo, pais que são alcoólatras e os filhos tem horror à bebida. Então, a família interfere } \\
\text { muito" (sic). }\end{array}$ \\
\hline P5 & $\begin{array}{l}\text { "Não acho que a família interfere, porque nós sempre nos dedicamos a ele, brincando, fazendo as } \\
\text { atividades tudo com ele (...). A família toda dá o maior apoio para ele" (sic). }\end{array}$ \\
\hline P6 & $\begin{array}{l}\text { "(...) A gente procura conversar mesmo com os atritos do casal, sou eu e ela, nada com os filhos. } \\
\text { Procuro respeitar a opinião de todo mundo, inclusive a deles" (sic). }\end{array}$ \\
\hline
\end{tabular}

Fonte: Elaborado pela autora, 2019.

Categoria Mudança de Comportamento e Práticas Parentais: Nesta categoria analisamos se os participantes estão dispostos a mudar alguns comportamentos em prol de seus filhos e quais suas expectativas nessas mudanças referente as práticas parentais.

\section{Quadro 8}

\begin{tabular}{|l|l|}
\hline P1 & $\begin{array}{l}\text { “(..) Já estou tentando. Que nem te falei, não gosto de abraço, não gosto de beijo, não consigo. Ai } \\
\text { quando ela vem, eu aguento... Antes eu já dizia pra sair, agora eu fico um pouco, depois eu fujo } \\
\text { dela (risos) (...). A gente se ajuda (...). O financeiro piora muito também a situação, às vezes as } \\
\text { crianças querem algo e eu não posso dar”" (sic). }\end{array}$ \\
\hline P2 & $\begin{array}{l}\text { “...) Conversar, eu converso, faço tudo que eu posso, se tiver alguma outra estratégia... Tem } \\
\text { coisas que a gente não enxerga. De expectativa, a melhora familiar, não sei se eu exijo demais, eu }\end{array}$ \\
\hline
\end{tabular}




\begin{tabular}{|c|c|}
\hline & $\begin{array}{l}\text { explico as coisas, não censuro tanto, que nem meus pais fizeram comigo. Tento achar um } \\
\text { equilibrio" (sic). }\end{array}$ \\
\hline P3 & $\begin{array}{l}\text { "Já estamos mudando alguns comportamentos. Eu até cheguei a pensar na época que ele começou } \\
\text { a ter problemas, tudo mudou na minha cabeça, mãe pensa em tudo, e uma das coisas que eu pensei } \\
\text { foi em questão da nossa rigidez dentro de casa, com os compromissos, com a responsabilidade na } \\
\text { escola, com a casa, com seus brinquedos... E ele é muito assim, ai fiquei pensando, será que é o } \\
\text { excesso... Foi ai que dei uma "mudadinha”, uma aliviada, e justamente pra ele poder se enquadrar } \\
\text { com a nova geração que está por ai (...). Mas acredito que se tem algo a mais pra mudar em casa, } \\
\text { sou eu, porque sou a mais severa, e também porque passo mais tempo com eles, por isso que o pai é } \\
\text { mais tranquilo..." (sic). }\end{array}$ \\
\hline P4 & $\begin{array}{l}\text { "Preciso ter mais paciência, acho que isso. A expectativa que eu tenho... É que eu parei de bater de } \\
\text { frente com ela, e eu fui para o diálogo e silêncio, em vez de bater boca, eu fico quieta, para ela } \\
\text { refletir e pensar. E eu vejo que isso tem resolvido, não fica nenhum ambiente pesado" (sic). }\end{array}$ \\
\hline P5 & $\begin{array}{l}\text { "Estou bem disposta a mudar. Inclusive não paguei algumas coisas, para comprar o cavalo para } \\
\text { ele, para ver se ele melhora, porque assim que ele está brabo, ele também é fácil da gente } \\
\text { conversar. Minha mãe me ajuda e me da umas ideias também para cuidar dele. Temos uma casa } \\
\text { atrás da nossa também, que queremos dar para ele, porque o quarto dele é dentro do nosso, ai para } \\
\text { ele ter mais liberdade também" (sic). }\end{array}$ \\
\hline P6 & $\begin{array}{l}\text { "Qualquer coisa que eu soubesse que pudesse melhorar o que está acontecendo com ela. Na } \\
\text { realidade, depois do que aconteceu com ela, a gente já mudou bastante, tentamos não discutir } \\
\text { tanto, nem gritar, nem pressionar muito ela. Estamos tentando" (sic). }\end{array}$ \\
\hline
\end{tabular}

Fonte: Elaborado pela autora, 2019.

Tabela 4 - Diálogos dos pais com índice de estilo parental (iep) positivo.

\begin{tabular}{|c|c|c|}
\hline Participantes & iep & Diálogos \\
\hline P3 & $\begin{array}{c}\text { Estilo } \\
\text { Parental } \\
\text { Bom }\end{array}$ & $\begin{array}{l}\text { "Colocamos pra fazer várias coisas, natação, futebol, para quando chegasse } \\
\text { em casa tivesse sono e não ter "tempo" para sentir medo..." (sic). } \\
\text { "Ele nunca me trouxe problema de espécie alguma, nem com escola, nem com } \\
\text { ninguém (...) não tenho o que dizer sobre ele, não vejo rebeldia, nem falta de } \\
\text { limites" (sic). } \\
\text { "Uma criança que tem responsabilidade, que tem compromisso, até demais } \\
\text { (...). Ele é tudo muito "além". Não tenho o que dizer, é responsável com as } \\
\text { tarefas dele, não preciso mandar (...)" (sic). } \\
\text { "Ele sabe que sou bem aberta para conversar e o pai também, nunca se opôs } \\
\text { a nada que fosse preciso, necessário para ele. Sobre dizer não: sempre, } \\
\text { sempre, sempre. Ele tem regras (...)" (sic). } \\
\text { "Acho que o que vem de casa vai para a vida toda. A gente cria os filhos, } \\
\text { sabendo que depois que casam, mudam a dinâmica deles, mas acredito que a } \\
\text { essência, o caráter a responsabilidade é a mesma, não muda”" (sic). }\end{array}$ \\
\hline P4 & $\begin{array}{c}\text { Estilo } \\
\text { Parental } \\
\text { Ótimo }\end{array}$ & $\begin{array}{l}\text { "Mudei a tática, discuto com ela dando o meu silêncio, e ela acaba } \\
\text { repensando. Então agora aprendi a lidar com ela (...). Fica tranquilo, um } \\
\text { ambiente saudável" (sic). } \\
\text { "[Fica difícil] quando ela está oscilando de humor, quando não toma } \\
\text { medicação. Então eu sentei com ela e conversei numa boa sobre a } \\
\text { medicação" (sic). }\end{array}$ \\
\hline
\end{tabular}




\begin{tabular}{|c|c|c|}
\hline & & $\begin{array}{l}\text { "Conversamos sobre tudo, sempre teve muito diálogo, sempre fui muito } \\
\text { aberta. Dou muito limite, só parei de dizer tanto "não", estou mostrando mais } \\
\text { pra ela os dois lados das situações, os caminhos... Tipo, "Não concordo com } \\
\text { isso, mas se tu fizeres vai ter tal reação". É ação e reação". Como ela já está } \\
\text { com } 17 \text { anos, estou dando mais essa abertura, de mostrar os dois lados da } \\
\text { moeda" (sic). } \\
\text { "A gente é um espelho para os filhos" (sic). }\end{array}$ \\
\hline P6 & $\begin{array}{c}\text { Estilo } \\
\text { Parental } \\
\text { Ótimo }\end{array}$ & $\begin{array}{l}\text { "Minha filha é quieta, na dela, se ela diz uma coisa, ela não volta atrás, ela } \\
\text { tem opinião" (sic). } \\
\text { "Ela é tranquila, é uma guria muito especial, sou suspeito para falar, eu amo } \\
\text { muito meus filhos" (sic). } \\
\text { "Eu sou bem flexivel, converso e tudo, só que a mãe deles diz não e depois } \\
\text { volta atrás se incomoda muito ela. Ai a gente já estabeleceu, que quando isso } \\
\text { acontecer é para ela dizer para ir falar comigo" (sic). }\end{array}$ \\
\hline
\end{tabular}

Fonte: Elaborada pela autora, 2019.

Tabela 5 - Diálogos dos pais com iep negativo.

\begin{tabular}{|c|c|c|}
\hline Participantes & iep & Diálogos \\
\hline P1 & $\begin{array}{c}\text { Estilo } \\
\text { Parental } \\
\text { de Risco }\end{array}$ & $\begin{array}{l}\text { "Eu só a via nos finais de semana (...). Ela ficou no abrigo por um ano". (sic). } \\
\text { "A minha filha não sei se faço errado, porque eu procuro ser amiga dela, não } \\
\text { sei se às vezes isso atrapalha" (sic). } \\
\text { "Ela perdeu um ano (de estudos), mas ela não estava comigo, foi naquela } \\
\text { transição..." (sic). } \\
\text { "Eu também sou "altos e baixos", então quando estão as duas... é dificil (...)" } \\
\text { (sic). } \\
\text { "Ela até que entende muito bem os limites, ela bate um "pezinho", mas não } \\
\text { desobedece, ela não se atreve (...) Eu só ameaço, às vezes, pra ver se faz } \\
\text { algum efeito" (sic). } \\
\text { "Porque quando eu estou mais "atacada" eu já não consigo tratar bem, e o } \\
\text { que acontece, eu não judio, nem bato... Mas também não trato bem... E ela é } \\
\text { muito melosa, e eu não sou assim, sei que ela quer estar abraçada, agarrada, } \\
\text { eu tenho aflição com isso..." (sic). }\end{array}$ \\
\hline $\mathbf{P 2}$ & $\begin{array}{c}\text { Estilo } \\
\text { Parental } \\
\text { de Risco }\end{array}$ & $\begin{array}{l}\text { "A gente conversa, ele ouve, depois faz tudo de novo" (sic). } \\
\text { "Porque é muito difícil colocar limites, e ele tem as estratégias dele, de } \\
\text { enrolar (risos), bem complicado." (sic). } \\
\text { "Ele é agitado, ele não conversa, ele grita (...)" (sic). }\end{array}$ \\
\hline
\end{tabular}




\begin{tabular}{|l|l|l|}
\hline & & $\begin{array}{l}\text { "Ele irrita, ele enfrenta, é meio agressivo com as palavras, mas depois ele vai } \\
\text { ter que aceitar, não adianta, ele é "de menor"'" (sic). }\end{array}$ \\
\hline P5 & $\begin{array}{c}\text { Estilo } \\
\text { Parental } \\
\text { de Risco }\end{array}$ & $\begin{array}{l}\text { "Quando brigamos eu fui dar uma "chinelada" nele e ele me retribuiu com um } \\
\text { saco no braço" (sic). } \\
\text { "Diz que não mando nele, quem ele manda em si, ai eu o acalmo. Só que de } \\
\text { vez em quando ele sai de si, desconta tudo em mim" (sic). } \\
\text { "A dificuldade é mais a questão dele não aceitar não, e nem ter limites" (sic). } \\
\text { "O problema é como eu disse, acontece algo com ele, ele desconta tudo em } \\
\text { mim (...)" (sic). }\end{array}$ \\
\hline
\end{tabular}

Fonte: Elaborada pela autora, 2019.

Na tabela 4 encontramos algumas falas dos pais retiradas da entrevista semiestruturada de acordo com o índice de estilos parentais (iep) positivos (Bom e ótimo). Já na tabela 5 estão algumas falas dos pais referente ao iep negativo (de risco).

\section{DISCUSSÃO}

A presente pesquisa teve por objetivo identificar os estilos parentais de pais de adolescentes em tratamento psicológico em um Centro de Atenção Psicossocial No Litoral Norte do RS, bem como verificar de que forma os estilos parentais influenciam na comunicação e no vínculo parental, como também a percepções dos pais aos comportamentos de seus filhos.

A análise de dados obtidos nesta pesquisa foi feita a partir do Método de Bardin (1977/2000). Para isso os conteúdos da entrevista foram divididos em categorias de análise, destacando-se os dados mais relevantes. Assim, juntamente com a fundamentação teórica, os dados obtidos na pesquisa corroboram para a melhor compreensão da interferência dos Estilos Parentais na fase da adolescência.

A partir dos dados obtidos no questionário sociodemográfico, apresentados na tabela 2 podemos observar que a pesquisa foi realizada com participantes com idade entre 32 e 46 anos, sendo que a escolaridade varia desde o ensino fundamental incompleto até ensino superior incompleto. Quanto ao estado civil, um participante é solteiro, com 04 filhos, quatro são casados com 03, 02, 01 e 02 filhos respectivamente, e uma viúva, com 02 filhos. Dos seis 
entrevistados, a idade dos filhos adolescentes varia de 12 a 17 anos e a renda mensal familiar de $\mathrm{R} \$ 260,00$ a $\mathrm{R} \$ 5.000,00$.

Constatou-se na pesquisa que dos seis participantes, somente um era do sexo masculino, porém todos apresentam seus cônjuges como auxiliares na educação dos filhos. Ao analisar como pais e mães percebem os papéis parentais na educação dos filhos, os resultados demonstraram a atribuição de papéis tradicionais, em que a mãe seria a maior responsável pela educação, carinho e afeto dos filhos. No caso dos pais, estes seriam responsáveis pelo exercício da autoridade, do ensino e da disciplina. Por outro lado, pais e mães ressaltam a importância da coparentalidade na educação dos filhos. Na percepção dos pais sobre a influência de outros fatores no exercício da parentalidade, observou-se que os avós e a escola foram influenciadores nesse processo (LINS et al, 2015).

De acordo com os dados do Inventário de estilos Parentais (2006), apresentados na tabela 3, podemos constatar que os resultados variam entre Estilo Parental de Risco (negativo), correspondentes a pais negligente e não responsivos e Estilo Parental Bom e Ótimo (positivo), referente a pais atenciosos e responsivos. Conforme o quadro 1 , na categoria "Motivo da procura ao CAPS" os pais relatam motivos em comum, como oscilações de humor, agitação, ansiedade e depressão. Os pais que estão com os índices de estilos parental (iep) bom e ótimo levaram seus filhos para tratamento por insônia e pensamentos obsessivos (P3), luto pela perda do pai (P4) e ausência no âmbito escolar por possível situação de bullying (P6). Já os pais com iep de risco trouxeram o motivo de abuso físico e mental (P1), faltas frequentes na escola, dificuldades em dar limites (P2 e P5). Percebe-se que os pais com iep ótimo (P4 e P6) procuraram atendimento a seus filhos por questões externas e situações esporádicas, que não tiveram relação aparente e direta com suas práticas parentais. O P3, mesmo com iep ser referenciado como "Bom", procurou o CAPS por conta de o filho estar com pensamentos obsessivos, podendo correlacionar com a rigidez e elevada responsabilidade atribuída a ele em todos os âmbitos da vida, relacionado ao comportamento moral em excesso, apresentadas na fala na da mãe: "É uma criança que tem responsabilidade, que tem compromisso, até demais (...). Ele tem regras (...). Geralmente o não vem primeiro" (sic). Além de apresentar pouca comunicação com o mesmo, o apresenta como uma criança, mesmo com seus 13 anos. Já os pais com iep de risco (P1, P2 e P5) apresentaram nesta categoria negligência, disciplina relaxada e punição inconsistente, diante das falas: "Ela sofreu um abuso (...) eu trabalhava a noite, deixei na babá (...), ficou um ano 
no abrigo" (sic); "A gente conversa, ele ouve, depois faz tudo de novo" (sic); "Dei uma chinela e ele me retribuiu com um saco no braço".

Na categoria "Representação da adolescência pelos pais" (quadro 2), os pais revelam a fase da adolescência complicada e de oscilações, alguns pensam ser igual sua época, as mesmas queixas e reclamações, outros explanam que a tecnologia tomou lugar do "olho a olho" nas interrelações. Os participantes P1, P2 e P5 relacionam a adolescência como uma fase complicada por não conseguir lidar com as oscilações, rebeldias e falta de controle, apresentando inconsistência na relação com seus filhos. Já os pais P3, P4 e P6 não demonstraram ter problemas com essa fase diretamente no comportamento de seus filhos, porém explanaram sobre a tecnologia e a temem nas relações sociais e emocionais de seus filhos: "Antes se conhecia mais a essência das pessoas, as emoções, o que sentiam, hoje não, não se sabe em uma conversa o que a pessoa está realmente sentindo" (sic). Quando as tecnologias digitais usadas de forma inadequada e excessiva, elas abrem uma lacuna nas relações familiares e deixam pais e filhos em mundos totalmente diferentes. A forma de como essas tecnologias digitais foram inseridas no contexto familiar vem alterando a forma como a família se reúne, e isso deixa claro evidenciando que o diálogo e a participação na vida dos adolescentes são muito importantes (SILVA E SILVA, 2017).

No quadro 3, categoria "Características comportamentais dos filhos adolescentes" correlacionou que pais com iep de risco possuem filhos agitados, nervosos, confusos (P1, P2 e P5). Estes pais não apresentam consistência na forma de lidar com as oscilações de seus filhos, se tornam nervosos, agitados e incompreensíveis perante os comportamentos indesejados, reproduzindo uma monitoria negativa, disciplina relaxada e punição inconsistente. Em decorrência da falta de equilíbrio, se desorientam produzindo frágeis funções parentais, visto que quando não conseguem se manter firmes em atitudes disciplinares com os filhos, reforçam a conduta de rebeldia que se reflete nas dificuldades enfrentadas por não saberem estipular regras que os conduzam adequadamente (BARRETO E RABELO, 2015). Já pais com o iep bom e ótimo têm filhos mais tranquilos, responsáveis e amorosos (P3, P4 e P6), pois utilizam o diálogo de forma positiva e moral.

Na categoria "Dificuldades na criação dos filhos e ajuda de outros" (quadro 4), os entrevistados P1, P2 e P5 têm ajuda dos cônjuges ou de membros da família, mas quem mais 
orienta e educa os filhos são eles. As dificuldades encontradas referem a falta de limites, oscilações de humor e dificuldades de diálogo. Já os entrevistados P3, P4 e P6 explanam a educação de seus filhos com ajuda mútua de seus cônjuges e/ou familiares, e utilizam mais diálogo e cooperação nas dificuldades encontradas. O diálogo dos pais com filhos adolescentes apresenta-se como grande desafio, pois é por meio de comunicação harmoniosa que a família vai redefinindo as novas representações de pais e filhos, priorizando, principalmente, a transmissão da afetividade através do respeito e cuidado (MORGADO et al, 2014).

No quadro 5, referente à categoria "Comunicação e limites”, podemos analisar que pais com ocupação e renda familiar maior possuem mais estabelecimento de limites e comunicação com seus filhos (P3, P4 e P6), obtendo monitoria positiva e comportamento moral: "Ele sabe que sou bem aberta para conversar e o pai também, nunca se opôs a nada que fosse preciso, necessário para ele. Sobre dizer não: sempre, sempre, sempre. Ele tem regras" (sic); "Conversamos sobre tudo, sempre teve muito diálogo, sempre fui muito aberta. Dou muito limite (...) estou mostrando mais pra ela os dois lados das situações, os caminhos" (sic); "(...) a gente conversa tranquilo. Sobre tudo (...) Eu sou bem flexível, converso e tudo". Já pais com baixa renda e desemprego possuem menor estabelecimento de limites e falta de diálogo mútuo, impondo regras a seus filhos sem conversarem sobre o assunto discutido (P1, P2 e P5), agindo de forma de forma negligenciada e com punições inconsistentes: "eu ameaço às vezes, pra ver se tem algum efeito" (sic); "ele irrita, ele enfrenta (...), mas não consigo dizer não" (sic); "eu pedia para ele ficar quietinho que já ia dar o que ele precisava" (sic).

Os pais devem proporcionar uma educação não rígida, que dê maior espaço para a participação do adolescente na família, promovendo formas de relações mais compreensivas e próximas, ao mesmo tempo em que reconheçam que o sujeito precisa ser orientado, em termos de limites, e respeitado dentro de suas possibilidades e capacidades características. Desse modo, proporcionar autonomia aos filhos não significa deixá-los livremente às suas vontades, visto que, além de caracterizar descuido com os filhos, expressa comportamento de abandono por não orientá-los à equilibrada liberdade de escolhas. É necessário assumir a intrínseca posição de líderes, buscando subsidiar continuamente, com diplomacia, as demandas relacionais dos filhos, conduzindo-os a uma efetiva formação (BARRETO E RABELO, 2015). 
A categoria "Ambiente familiar e tempo de convívio" (quadro 6) apresentou a seguinte perspectiva: Entrevistados P1, P3, P4 e P5 possuem ambiente familiar tranquilo com significativa interação e tempo de convívio. Já os participantes P2 e P6 possuem um ambiente mais agitado e de pouco interesse afetivo e tempo significativo de convívio, não obtendo ligação com os índices dos estilos parentais, visto que o primeiro possui iep de risco e o segundo iep ótimo. Já no quadro 7 com a categoria "Convívio familiar e implicações no comportamento do adolescente" todos os participantes, exceto o P5 dizem que o convívio familiar interfere no comportamento de seus filhos. Demonstram-nos também que seus humores mudam suas atitudes com eles de acordo com a situação. A instabilidade de humor dos pais provoca uma interação inconstante com os filhos, causando dificuldades no aprendizado de valores morais transmitidos, já que passam a perder o respeito pela autoridade exercida pelos pais. Dessa forma, o comportamento antissocial é visto como uma consequência das práticas abusivas de maus-tratos, assim como pelo desinteresse dos pais no cuidado com os filhos, daí a necessidade de se adotar um estilo parental pautado na constância de atitudes equilibradas que possam promover um bom desenvolvimento moral dos filhos (BARRETO E RABELO, 2015).

Na categoria "Mudança de comportamento e práticas parentais" (quadro 8) todos os participantes disseram estar dispostos a mudanças parentais em prol de seus filhos e que já estão fazendo tais mudanças. Gomide (2006) salienta que é de extrema importância que os pais reflitam junto com os filhos sobre os comportamentos emitidos, ensinando se colocar no lugar dos outros e propiciando situações para que ela repare seus atos no intuito de promover reflexões, desenvolverem a empatia, e consequentemente o comportamento moral. Para tanto, os pais necessitam comportarem-se de forma socialmente adequada, isto é, sendo socialmente habilidosos ao invés de agressivos e/ou não assertivos, a fim de promover a competência social daqueles.

As práticas educativas parentais positivas são definidas pela monitoria positiva e o comportamento moral, sendo observadas nas falas dos pais P3, P4 e P6 na tabela 4. Já as práticas educativas negativas envolvem a negligência, a ausência de atenção e afeto, o abuso físico e psicológico, ameaça e chantagem de abandono e de humilhação do filho, a disciplina relaxada, o relaxamento de regras estabelecidas, punições inconsistentes, em que os pais se 
orientam por seu humor na hora de punir ou reforçar e não pelo ato praticado e a monitoria negativa, caracterizado pelo excesso de instruções independente de seu cumprimento e consequentemente, pela geração de um ambiente de convivência hostil apresentadas na pelas falas dos participantes $\mathrm{P} 1, \mathrm{P} 2$ e P5 na tabela 5. Tanto as práticas educativas positivas como as negativas podem influenciar a criança no desenvolvimento de habilidades (GOMIDE, 2006).

Gomide (2004), afirma que atualmente os pais se afastaram das regras rígidas de educação de filhos. Passaram a ceder mais, repudiam a punição física, quiseram se tornar mais amigos dos filhos, começando a utilizar o diálogo como fonte de educação. Entretanto, ao mesmo tempo, identifica-se na sociedade contemporânea o aumento significativo dos comportamentos antissociais. Pais omissos não se envolvem em nada; focalizam sempre os erros e esquecem de valorizar os acertos; as regras dependem do humor; não estabelecem regras; usam disciplina exagerada com xingamentos, gritos e discussões. Pais presentes sabem que o afeto constrói confiança e resiliência; valorizam comportamentos corretos e criativos; definem regras e limites e as mantém independente de seu humor; conseguem ter autocontrole.

\section{CONSIDERAÇÕES FINAIS}

Esta pesquisa teve por objetivo identificar os estilos parentais de pais de adolescentes em tratamento psicológico em um Centro de Atenção Psicossocial do litoral norte do RS, bem como verificar de que forma os estilos parentais influenciam na comunicação parental e qual a percepção destes pais frente aos comportamentos de seus filhos.

Nas famílias que o índice de estilos parental foi de risco (P1, P2 e P5) apresenta-se a prevalência das práticas educativas negativas, o uso dessa prática envolve a punição inconsistente, negligência, disciplina relaxada, monitoria negativa e abuso físico. Nesses estilos parentais de risco as práticas educativas podem ser caracterizadas por fiscalização e ordens excessivas dadas aos filhos, pelo não cumprimento de regras estabelecidas, os pais estabelecem regras mais quando confrontados abrem mão. Outro fator relevante do estilo parental de risco é que os pais podem ser negligentes e não responsivos, aplicando punições inconsistentes, que se retiram das situações difíceis, não aceitando suas responsabilidades, 
ignorando a maioria dos comportamentos da criança, desencadeando sentimentos de insegurança, vulnerabilidade, tornando-a hipersensível, relacionando com a teoria de Baumrind (1966), podemos caracterizar esses pais com estilos autoritários, permissivos e negligentes.

Já nas famílias com o Índice de Estilos Parentais Bom e Ótimo (P3, P4 e P6) envolvem a monitoria positiva e o comportamento moral, relacionado com o estilo autoritativo (BAUMRIND, 1966) prevalecendo o uso adequado da atenção e distribuição de privilégios, estabelecendo regras e promovendo condições favoráveis ao adolescente em desenvolvimento de virtudes, como empatia, senso de justiça, responsabilidade, trabalho, generosidade e o conhecimento do que é certo ou errado.

O estudo apresentou limitações referentes ao tamanho da amostra, apresentada em número reduzido, considerando os resultados obtidos apenas para a população em questão. Sugere-se a continuação dos estudos nesta temática, considerando que a percepção dos pais é influenciada pelas suas características pessoais, da criança e do seu contexto. Portanto, a compreensão do papel parental tende a interferir na maneira como cuidam e interagem com os seus filhos, motivando as suas práticas parentais e apontando para padrões de comportamentos, verificando também a diferença dos estilos parentais entre mães, pais e/ou responsáveis, com amostras maiores e em diferentes contextos.

\section{REFERÊNCIAS BIBLIOGRÁFICAS}

ANDRADE, M. L. et al. Vínculos familiares e atendimento psicológico: a escuta dos pais sobre a alta da criança. Revista da SPAGESP, p. 5-13, 2012.

BOCK, A. M. B. A adolescência como construção social: estudo sobre livros destinados a pais e educadores. Revista Semestral da Associação Brasileira de Psicologia Escolar e Educacional (ABRAPEE). Volume 11, número 1 Janeiro/Junho, 2007. 
BARRETO, M.J.; RABELO, A. A.; A família e o papel desafiador dos pais de adolescentes na contemporaneidade. Porto Alegre, v. 19, n. 2, p. 34-42, 2015.

BARDIN, L. Análise de conteúdo. Lisboa: Edições 70, 1977. 226p

BOLSONI-SILVA, A.T.; LOUREIRO, S.R. Práticas educativas parentais e repertório comportamental infantil: comparando crianças diferenciadas pelo comportamento. Paidéia, 21 (48): 61-71, 2011.

BRÁS, P.M.F. Um olhar sobre a parentalidade (estilos parentais e aliança parental) à luz das transformações sociais actuais. Lisboa, 2008.

BAUMRIND, D. Effects of authoritative control on child behavior. Child Development, 37, 887-907, 1966.

BAUMRIND, D. The Influence of Parenting Style on Adolescent Competence and Substance Use. Journal of early adolescence, 1989.

BRASIL. Lei no 8.069, de 13 de julho de 1990. Dispõe sobre o Estatuto da Criança e do Adolescente e dá outras providências. Diário Oficial da República Federativa do Brasil, Brasília, DF, 1990.

BRONFENBRENNER, U. A ecologia do desenvolvimento humano: experimentos naturais e planejados. Porto Alegre, Artes Médicas, p. 267, 1996.

CAMPOS, C. J. G.; TURATO, E.R. Análise de conteúdo em pesquisas que utilizam metodologia clínico-qualitativa: aplicação e perspectivas. Rev. Latino-Am. Enfermagem, Ribeirão Preto, v. 17, n. 2, p. 259-264, 2009.

CARDOSO, J. VERÍSSIMO, M. Estilos parentais e relações de vinculação. Análise Psicológica, p. 393 - 406, 2013. 
CALLIGARIS, C. A adolescência. São Paulo, $2^{\circ}$ ed., 2009.

GOMIDE, P. I. C. Pais presentes, pais ausentes: regras e limites. Ed. Vozes. Petrópolis, RJ, 2004.

GOMIDE, P. I. C. Inventário de Estilos Parentais. Modelo teórico: manual de aplicação, apuração e interpretação. Petrópolis: Vozes, 2006.

GUNTHER, H. Pesquisa Qualitativa Versus Pesquisa Quantitativa: Esta É a Questão? Psicologia: Teoria e prática, vol.22, nº 2, 2006.

JORDÃO, A. B. Vínculos Afetivos de Adolescentes Borderline e seus Pais. Psicologia: Teoria e Pesquisa, 2010, Vol. 26 n. 1, pp. 89-98.

LINS, Z. M. B. et al. O papel dos pais e as influências externas na educação dos filhos. Rev. SPAGESP, Ribeirão Preto, v. 16, n. 1, p. 43-59, 2015.

MALUF, A. C. R. F. D. Novas modalidades de família na pós-modernidade. São Paulo: Atlas, 2010.

MORGADO, L. V. et al. Ciclo vital da família: A comunicação entre pais e filhos na fase adolescente. III Congresso Internacional de Ciência. Tecnologia e Desenvolvimento. Ciência e Tecnologia para o Desenvolvimento Social. 20 a 22 de outubro, 2014.

OSÓRIO, L.C. Família hoje. Porto Alegre: Artes Médicas, 1996.

PARDO, M. B. L.; CARVALHO, M. M. S. B. Grupos de orientação de pais: estratégias para intervenção. Contextos Clínicos, São Leopoldo, v. 5, n. 2, p. 80-87, 2012. 
PRATTA, E. M. M.; SANTOS, M.A. Família e adolescência: A influência do contexto familiar no desenvolvimento psicológico de seus membros. Psicologia em Estudo, Maringá, v. 12, n. 2, p. 247-256, 2007.

ROUDINESCO, E. A família em desordem. Rio de Janeiro: Jorge Zahar Editor, 2003.

RUZANY, M.H; et al. Comunicação entre a família e seus filhos adolescentes: construindo uma relação dialógica. Adolesc. Saúde. 2008, p29-38.

SAMPAIO, I, T, A.; GOMIDE, P, I, C.; INVENTÁRIO DE ESTILOS PARENTAIS (IEP) - Gomide (2006) PERCURSO DE PADRONIZAÇÃo E NORMATIZAÇÃo. Psicol. Argum. Curitiba, v. 25, n. 48 p. 15-26, 2007.

SCHNEIDER, N. et al. Vínculo parental e rede de apoio social: relação com a sintomatologia depressiva na adolescência. Aletheia, Universidade Luterana do Brasil Canoas, 2007, pp. 95-108.

SILVA, T. O; SILVA, L. T. G. Os impactos sociais, cognitivos e afetivos sobre a geração de adolescentes conectados às tecnologias digitais. Rev. Psicopedag., São Paulo, v. 34, n. 103, p. 87-97, 2017.

STEINBERG, L. We know some things: parent-adolescent relationships in retrospect and prospect. Journal of Research on Adolescence, 11 (1), 1-19, 2001.

WAGNER, Adriana et al. A comunicação em famílias com filhos adolescentes. Psicologia em estudos, Maringá, v. 7, n. 1, p. 75-80, 2002.

WAGNER, Adriana et al. Estratégias de Comunicação Familiar: A Perspectiva dos Filhos Adolescentes. Psicologia: Reflexão e crítica, PUC, 18(2), pp.277-282, 2005.

ZAMBERLAM, C. O. Os novos paradigmas da família contemporânea: Uma perspectiva interdisciplinar. Rio de Janeiro: Renovar, 2001. 